\title{
Differentiation of Glandular Cavities in the Vascular Bundles of Developing Peach Fruit
}

\author{
Naosuke Nii*, Chun Xiang Pan** and Yoshinori Nakao \\ Faculty of Agriculture, Meijo University, Tempaku, Nagoya 468-8502
}

\begin{abstract}
Summary
The anatomical differentiation of glandular cavities in the vascular bundle in the peach mesocarp was investigated throughout the fruit growing period. The glandular elements first appeared in the parenchyma cells of xylem tissues adjacent to the cambium by a schizogenous process. The limits of the glandular cavity were established by May 16 (36 days after full bloom, AFB); the general structure was completed on May 23, which was about one week before the beginning of sugar accumulation in the mesocarp. In cross-sections of a vascular bundle, the cavity appears as a large circle, whereas in the long sections, it appears to be similar to a smoker's pipe. The structure is present in every vascular bundle of the peach flesh. Consequently, they form a network with other vascular bundles.
\end{abstract}

Key Words: glandular cavity, peach fruit, sugar accumulation, vascular bundle.

\section{Introduction}

Nii (1990) first observed glandular cavities in peach fruit. Thereafter, Masia et al. (1992) reported in detail the structure of the glandular cavity by light and transmission electron microscopy (TEM) and polysaccharide accumulation in the glandular cavity. They reported that the glandular elements in the vascular tissues were recognizable at an early stage of fruit development, five weeks AFB. Under TEM, a mucilage-like material with a loose fibrillar net was observed in the glandular cavities, perhaps it was produced by a few cells that formed the cavity. Although Masia et al. (1992) reported detailed observations of a mature glandular cavity, changes in the anatomical characteristics are not wellunderstood in relation to fruit development. Particularly, the initiation of glandular cavity has not been reported. Knowledge regarding anatomical changes of the glandular cavity in the peach fruits should contribute to our understanding of fruit physiology. This work seems to be the first to describe the initiation and development of glandular cavity in the developing peach fruit, from anthesis to maturity.

In this study, the anatomical differentiation of the glandular structure was observed cross- and lengthwise throughout the growing period of the peach fruit to understand its role.

\section{Materials and Methods}

Peach (Prunus persica (L.) Batsch 'Takei-hakuho') flowers and fruits on several large 10-year-old trees in

Received; March 4, 2004. Accepted; July 21, 2004.

* Corresponding author (E-mail: nii@ccmfs.meijo-u.ac.jp).

** Present address: Shaoguan University, Shaoguan 512005 . China. the experimental orchard at Meijo University (Kasugai) were sampled periodically from full bloom (April 10) to harvest (June 27) in 2001. On each sampling date, the cheek diameters (length parallel to the suture of the fruit) and weights of 4 to 14 fruits were determined, recorded, and plotted as cumulative curves.

Samples of tissue taken from the equatorial diameter of the pericarp were fixed in $3 \%$ glutaraldehyde $(0.1 \mathrm{M}$ cacodylate buffer, $\mathrm{pH}$ 7.2) and dehydrated in a gradient series of ethyl alcohol. Tissues were embedded in Technovit 7100 (Kulzer, Germany) and sections (1.5 $\mu \mathrm{m})$ therefrom were cut by a glass knife with an ultramicrotome, and stained with methylene blue.

When the pericarp ripened, sections of the fruits were squeezed and the soluble carbohydrates in the resulting juice analyzed as follows: the juice was filtered and a $10-\mu 1$ subsample of the filtrate was injected into an HPLC equipped with a Shodex $\mathrm{CH}-801$ column. The column was eluted with water at $1 \mathrm{ml} \cdot \mathrm{m}^{-1}$.

\section{Results and Discussion}

The plot of the peach growth curve as cheek diameter conformed to a double-sigmoid curve with its three fruit growth stages: stage I (S-I) was from anthesis (April 10) to May 28; stage II (S-II) extended from May 28 to June 15; followed by stage III (S-III) that lasted from June 15 to harvest, June 27 (Fig. 1). Fruit weight increased markedly at the final stage (S-III). The mean fruit weight was $85.9 \mathrm{~g}$ on June 15 (66 days AFB); it increased to $234.0 \mathrm{~g}$ on June 25 . An increase in sugar content in the juice was detected during S-II (Fig. 2). On and after May 28 (48 days AFB) the sugar (sucrose, glucose, and fructose) content increased rapidly. In particular, sucrose increased continuously until ripening; the other sugars decreased during ripening, as reported 


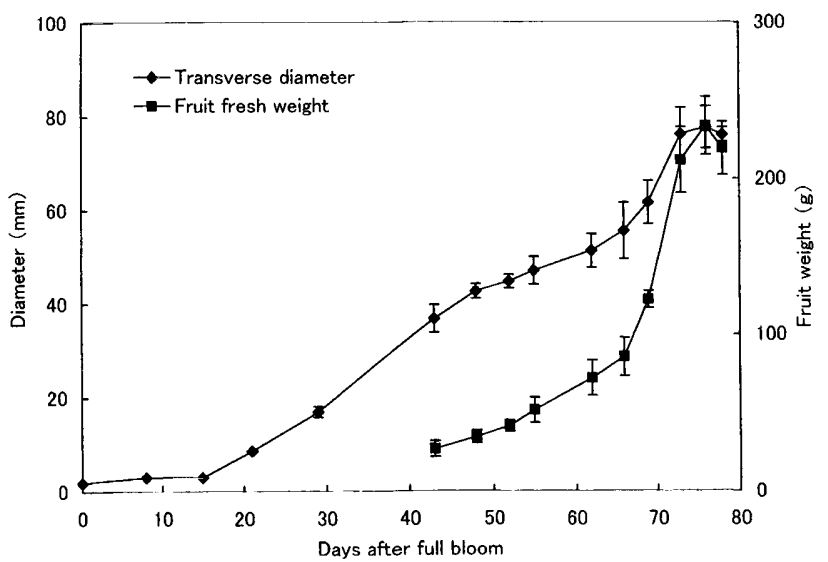

Fig. 1. Cumulative growth curves of peach fruit in terms of fruit diameter (transversal length to the suture of the fruit) and fresh weight throughout the growing season. Vertical lines are $S D(n=4-14)$.

by Moriguchi et al. (1990).

The glandular cavity in the vascular bundle of the peach flesh was not observed on May 1 (Fig. 3A, B), but its initial features appeared between May 9 (29 days AFB) to May 16 (Fig. 3C, D, and Fig. 4A, B). The glandular cavity differentiated from the central part of the vascular bundle; the first glandular elements became recognizable in the parenchyma cells of xylem tissues adjacent to the cambium. These gland initials could thus be distinguished from surrounding parenchyma cells in the xylem; the central cells of gland initials had large, round nuclei (Fig. 3D, Fig. 4A-D). The cavity formed schizogenously through a separation of the walls of several parenchyma cells that were pushed outwardly and flattened by cavity expansion (Fig. 4E, F). The general structure of the cavity was completed between May 16 (36 days AFB) and May 23, about one week before the onset of sugar accumulation (Fig. 2). These cavities appeared in every vascular bundle of the flesh (Fig. 5A). When the differentiation of the glandular cavity was completed, it appeared as a circle in cross sections but as a smoker's pipe in the long section (Fig. $5)$. The glandular cavity area was larger in vascular bundles in mature fruits (Fig. 5B). Thus, the glandular cavity is connected continuously in the network of vascular bundles. A glandular cavity did not appear in vascular bundles of other organs in peach trees (Nii, 1979; Nii et al., 1998).

TEM of a glandular structure revealed secretory cells, rich with hyperactive Golgi bodies (Masia et al., 1992), with abundant vesicles that fuse with the plasmalemma to discharge their contents. Furthermore, TEM of the central cavity shows that the glandular structures contain much mucilaginous material with a loose fibrillar net

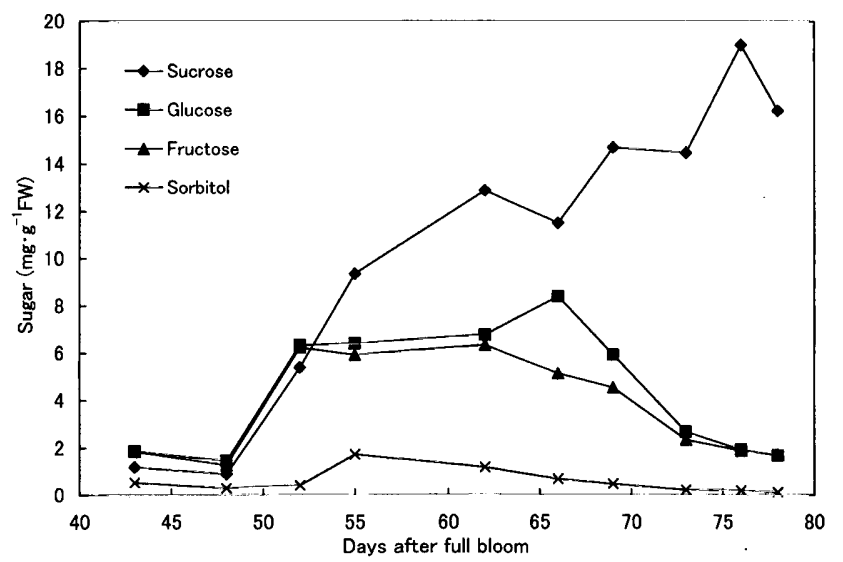

Fig. 2. Seasonal changes in soluble carbohydrates in peach fruit. Carbohydrate content is expressed as $\mathrm{mg} \cdot \mathrm{g}^{-1} \mathrm{FW}$.

produced by a few cell layers surrounding it. Generally, cavities and canals differ from secreting cells in that they are intercellular spaces that result from either a dissolution of cells, lysogeny or a separation of cells from one another, schizogeny. Our present observations lead us to believe that glandular cavity formation appears to involve schizogeny during early fruit development. No evidence for lysogeny was observed during the period because there was no sign of structural degeneration. At the onset of cavity formation, cells surrounding the cavity appeared to be structurally intact; a number of them exhibited densely stained nuclei (Fig. 3D and Fig. 4C-F).

In conclusion, glandular cavity initiation was restricted to early stages of fruit development. All cavities matured in immature fruit, but they continued to enlarge with vascular bundle development throughout the fruit growth period. The period of rapid cavity enlargement occurred in fruit with diameters between $21 \mathrm{~mm}$ and 41 $\mathrm{mm}$, which coincides with the period of cell enlargement in the mesocarp. The differentiation of the glandular structure approached completion about one week before sugar accumulation began in the mesocarp; that in turn corresponds to the period of cell enlargement. All cavities were joined to each other through the branching vascular bundles. Furthermore, the glandular cavity occupied most of the vascular bundle which indicate that they may play a role as a site for sugar accumulation by allowing polysaccharide accumulation (Masia et al., 1992). Although the glandular structure showed secretory cells, their functions need to be investigated for a better understanding of their role in peach fruit development. 


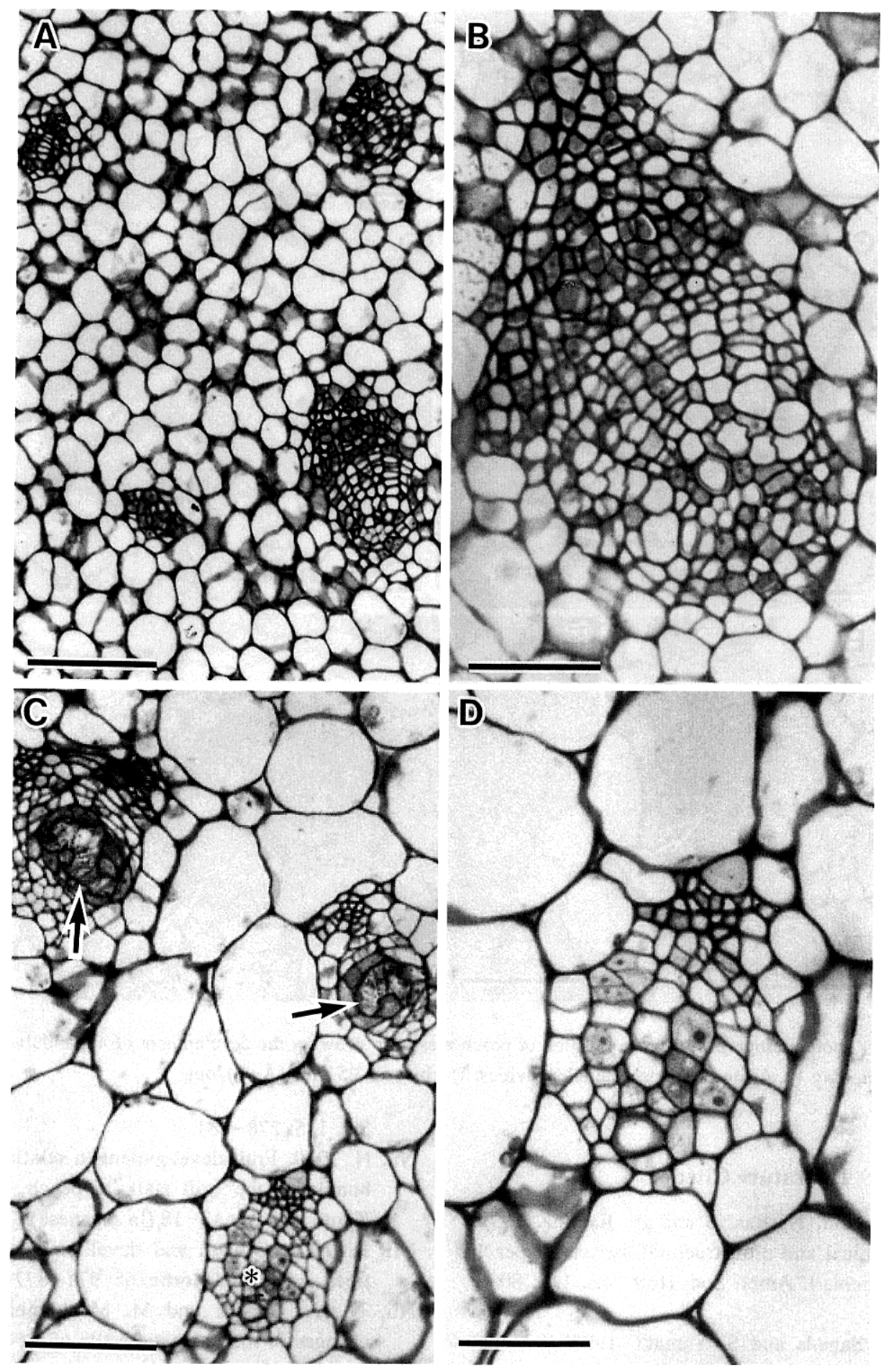

Fig. 3. Photomicrographs of cross ${ }^{-}$section of peach flesh. Arrows point to glandular cavities. A and B, on May 1; $\mathrm{C}$ and D, on May 16. B and D detail from A and $\mathrm{C}\left({ }^{*}\right)$. The bars are $50 \mu \mathrm{m}(\mathrm{A}, \mathrm{C})$ and $25 \mu \mathrm{m}(\mathrm{B}, \mathrm{D})$ long. 

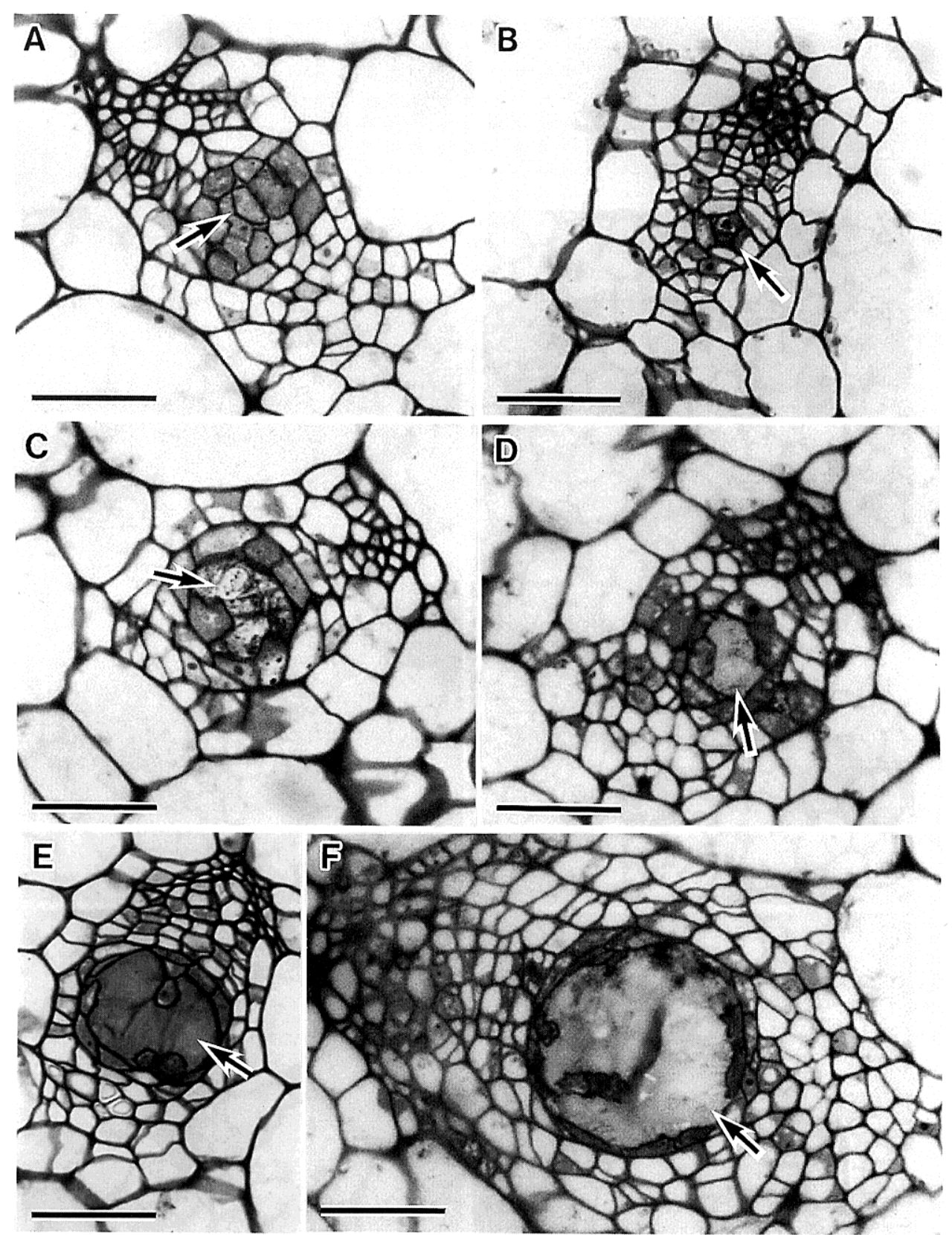

Fig. 4. Photomicrographs of cross ${ }^{-}$section of peach mesocarp showing the development of a glandular cavity on May 16. Arrows point to glandular cavities. The bars are $25 \mu \mathrm{m}(\mathrm{A}-\mathrm{F})$ long.

\section{Literature Cited}

Masia, A., A. Zanchin, N. Rascio and A. Ramina. 1992. Some biochemical and ultrastructural aspects of peach fruit development. J. Amer. Soc. Hort. Sci. 117: 808815.

Moriguchi, T., T. Sanada and S. Yamaki. 1990. Seasonal fluctuations of some enzymes relating to sucrose and sorbitol metabolism in peach fruit. J. Amer. Soc. Hort.

\section{Sci. 115: 278-281.}

Nii, N. 1979. Fruit development in relation to the vascular bundle of the fruit stalk in peach. Stud. Inst. Hort., Kyoto Univ. 9: 13-18 (in Japanese).

Nii, N. 1990. Growth and development of fruit and fruit trees. Agric. and Hortic. 65: 971-877 (in Japanese).

Nii, N., A. Chisaki and M. Mochizuki. 1998. Seasonal changes in the nacreous walls of sieve elements in the petioles of peach and apple leaves. Sci. Rept., Fac. Agr., Meijo Univ. 34: 13-24. 

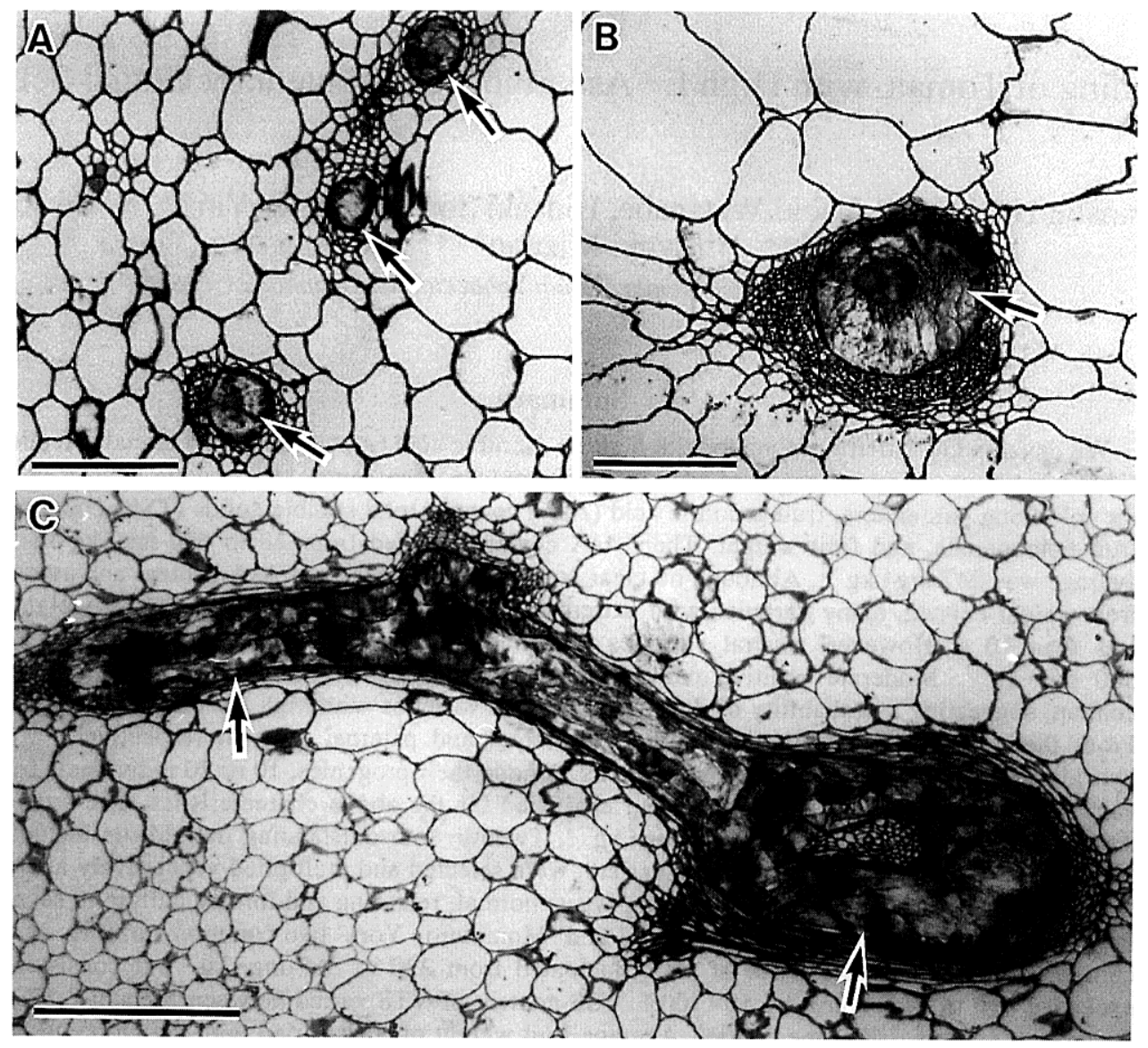

Fig. 5. Photomicrographs of cross- ${ }^{-}$section (A, B) and longitudinal section (C) of peach mesocarp. Arrows point to glandular cavities. A, peripheral mesocarp sampled on June 11; B, deeper mesocarp sampled on June 27; C, longitudinal section on May 23 showing a glandular cavity shaped like a smoker's pipe. The bars are $100 \mu \mathrm{m}(\mathrm{A}, \mathrm{B})$ and $200 \mu \mathrm{m}(\mathrm{C})$ long.

モモの果実発育に伴う果肉維管束内腺腔の発達

新居直祐・潘 春香 $* \cdot$ 中尾義則

名城大学農学部 468-8502 名古屋市天白区

摘 要

モモ‘武井白鳳’(Prunus persica (L.) Batsch) を供試し, 果肉の維管束内に出現する腺腔の発達過程を果実生長に関 連づけて細胞組織学的に観察した。維管束の横断面でみる と, 腺腔の分化始期では形成層に近い木部内の数個の柔細胞 が分離し，その後, 細胞間隙は次第に拡大し, 大きな腺腔を 形成していった. 開花 36 日後の 5 月 16 日には多くの維管束 内に腺腔が出現し, 開花 43 日後には完成した. この時期は果
汁中の糖含量が増加する約 1 週間前であった. 腺腔は果肉中 のすべての維管束に出現し, 維管束の横断面では巨大な円形 状を呈し, また縦断面では 1 本の長い管状となり, 各維管束 を通じて連結していた。

* 現在 : 韶関学院 512005 広東省韶関市大塘路 中国. 